\title{
ACCELERATED AGING AND ELECTRICAL CONDUCTIVITY TESTS IN CRAMBE SEEDS
}

\author{
Teste de envelhecimento acelerado e condutividade elétrica em sementes de crambe
}

\author{
Juliana Joice Pereira Lima1, Marcella Nunes de Freitas², Renato Mendes Guimarães ${ }^{3}$, \\ Antônio Rodrigues Vieira ${ }^{4}$, Maria Alice Bento Ávila ${ }^{3}$
}

\begin{abstract}
The aim of this study was to adapt the methodology of the accelerated aging and electrical conductivity tests for determination of physiological potential in crambe seeds. Six seed lots of crambe (cv. FMS Brilhante) were subjected to determination of moisture content, germination test, first count germination, emergence, and emergence speed index. For the accelerated aging test, the traditional methodology was used with water, and with a saturated potassium chloride and sodium chloride solution in three periods of exposure $\left(24,48\right.$, and 72 hours) at $41^{\circ} \mathrm{C}$; the electrical conductivity test was performed with four pre-soaking treatments $(0,2,4$, and 8 hours) and four soaking periods $\left(4,8,16\right.$, and 24 hours) at $25^{\circ} \mathrm{C}$. The accelerated aging test with water for 72 hours and the electrical conductivity test with 2 hours of pre-soaking and assessment after 16 hours were effective for classification of the crambe seed lots in regard to physiological quality.
\end{abstract}

Index terms: Crambe abyssinica, vigor, physiological quality.

\section{RESUMO}

Conduziu-se esta pesquisa, com o objetivo de adequar a metodologia dos testes de envelhecimento acelerado e condutividade elétrica para determinação do potencial fisiológico em sementes de crambe. Seis lotes de sementes de crambe cultivar FMS Brilhante foram submetidos à determinação do teor de água, teste de germinação, primeira contagem de germinação, emergência, índice de velocidade de emergência. Para o teste de envelhecimento acelerado, foi utilizada a metodologia tradicional com o uso de água e com solução saturada de cloreto de potássio e cloreto de sódio em 3 períodos de exposição $(24,48$ e 72 horas $)$ a $41^{\circ} \mathrm{C}$; o teste de condutividade elétrica foi realizado com quatro tratamentos de pré-embebição $(0,2,4$ e 8 horas) e quatro períodos de embebição $\left(4,8,16\right.$ e 24 horas) a $25^{\circ} \mathrm{C}$. O teste de envelhecimento acelerado com água por 72 horas e o teste de condutividade elétrica com 2 horas de pré- embebição e avaliação, após 16 horas, foram eficientes para a classificação dos lotes de sementes de crambe quanto à qualidade fisiológica.

Termos para indexação: Crambe abyssinica, vigor, qualidade fisiológica.

\section{INTRODUCTION}

Crambe (Crambe abyssinica Hochst) is a species that is a member of the Brassicaceae family, with drought and cold tolerance (Cardoso; Binotti; Cardoso, 2012). In addition to these properties, other factors, such as its hardiness, short cycle (Paulose; Kandasamy; Dhankher, 2010), low production cost (Jasper; Biaggioni; Silva, 2010), and its oil content greater than $40 \%$ (Souza et al., 2009), contribute to making crambe a winter crop option under the climatic conditions of some regions of Brazil (Southeast, South, and Center West).

Studies on the crambe crop are recent, few, and inconclusive, especially in regard to seed quality control. The vigor is one of the attributes present in seed lots of superior quality. According to AOSA (1983), seed vigor comprises those properties that determine the potential for rapid and uniform emergence and development of normal seedlings under a wide range of field conditions. Among the vigor tests used on seeds for quality control, the electrical conductivity and accelerated aging tests, in terms of standardization, are potentially adequate for crambe seeds since they provide reproducible results and are also easily performed at low cost (Hampton; TeKrony, 1995; Soares et al., 2010).

According to Vieira et al. (2002), the electrical conductivity test consists of indirect assessment of the state of organization of the cell membranes through determination of the quantity of leachates released by seeds in the soaking solution. In seeds of canola, a Brassicacea oilseed crop, Milani, Menezes and Lopes

\footnotetext{
${ }^{1}$ Universidade Estadual Paulista “Júlio de Mesquita Filho”/UNESP - Rua José Barbosa de Barros - 1780 - Fazenda Experimental Lageado - $18610-307$ Botucatu - SP - Brasil - juliana_lima@fca.unesp.br

¿Universidade de São Paulo/USP - Escola Superior de Agricultura "Luiz de Queiroz"/ESALQ - Piracicaba - SP - Brasil

3Universidade Federal de Lavras/UFLA - Departamento de Agricultura/DAG - Lavras - MG - Brasil

${ }^{4}$ Empresa de Pesquisa Agropecuária de Minas Gerais/EPAMIG - Lavras - MG - Brasil

Received in august 25, 2014 and approved october 6, 2014
} 
(2012) observed that the electrical conductivity test distinguished seed lots in regard to vigor after 8 hours. A similar recommendation is made by Torres et al. (2009) for sesame seeds. Nevertheless, Santos and Rosseto (2013) suggest that it is possible to distinguish seeds lots of crambe after 24 hours of soaking. For the same species, Cruz et al. (2013) do not recommend use of the electrical conductivity test for vigor assessment.

The capacity of reorganization of membranes by the seed at the beginning of the soaking process directly affects the quantity and nature of the solutes released to the outside medium (Krzyzanowski; Vieira; Franca-Neto, 1999). These solutes modify the electrical conductivity of the soaking water as a function of the amount of leached material, providing a direct relationship to the state of the seed cell membrane system. Soaking the seeds for a period before the electrical conductivity test would allow a pre organization of the membrane system and may reduce the interference of large amounts of solutes released in the early hours of soaking in the electrical conductivity test leading to more reliable results.

Barbosa et al. (2012) observed that peanut seeds with higher hydration exhibit lower electrical conductivity values and the quantity of leached solutes becomes stable more quickly in relation to dry seeds, providing results more in line with the physiological quality of the lots.

In the traditional methodology of the accelerated aging test, the use of water in the mini aging chamber is recommended, with variation in the exposure time and temperature according to the species (Jianhua; McDonald, 1996). Salt saturated solutions may also be used in this test for the purpose of reducing relative humidity within the plastic boxes, resulting in reduction in the speed of seed hydration.

Toledo et al. (2011) assessed the physiological quality of crambe seeds by the accelerated aging test with water, varying the temperature from 38 to $41{ }^{\circ} \mathrm{C}$ for 24 to 72 hours. They observed that the methodology was not effective in distinguishing the lots in regard to physiological quality. In contrast, Santos and Rosseto (2013), studying the same species, affirmed that the use of a sodium chloride saturated solution for 48 hours is effective. Werner et al. (2013) concluded that the accelerated aging test with water for 72 hours allows distinguishing the lots in regard to vigor. Cruz et al. (2013) mentioned that $42^{\circ} \mathrm{C}$ for 72 hours would be the recommended treatment for this species.

Although there are studies with a view toward adaptation of the methodology of the accelerated aging and electrical conductivity tests for crambe seeds, up to now, results have been divergent. Therefore, this study was conducted with the aim of adapting the methodology of the accelerated aging and electrical conductivity tests for determination of the physiological potential of crambe seeds.

\section{MATERIAL AND METHODS}

The study was carried out at the Central Seed Analysis Laboratory of the Universidade Federal de Lavras using six seed lots of crambe of the FMS Brilhante cultivar from the 2011 crop season, produced in the experimental field of EPAMIG in Lavras, MG, and stored in paper packaging in cool storage $\left(15^{\circ} \mathrm{C}\right.$ and $55 \% \mathrm{RH}$ ) up to the beginning of the experiment in March 2012. Moisture content was determined by keeping the seeds in a laboratory oven at $105^{\circ} \mathrm{C}$ for 24 hours with four replications of $4.5 \mathrm{~g}$ of seed (Brasil, 2009). The germination test was carried out according to Brasil (2009) using a sand substrate moistened with $0.2 \%$ potassium nitrate $\left(\mathrm{KNO}_{3}\right)$ at $60 \%$ holding capacity. Four subsamples of 50 seeds were sown in plastic boxes in washed and sterilized sand. At seven days after sowing, germination was evaluated and the results were expressed in mean percentages of normal seedlings (Brasil, 2009). On the fourth day of the germination test, normal seedlings were counted, expressed in percentage of first count germination.

The seedling emergence test was carried out through sowing in plastic boxes with a dirt: sand substrate in the proportion $1: 2$ and field capacity of $60 \%$ kept in a plant growth chamber at $25^{\circ} \mathrm{C}$ and 12 hour photoperiod. Four replications of 50 seeds per treatment were used, and the results were expressed in percentage of normal seedlings on the 14th day. Parallel to the emergence test, the speed of emergence was determined through a daily count of the number of emerged seedlings, calculated by the formula proposed by Maguire (1962).

The methodology of the accelerated aging test was studied with the use of three separate solutions: distilled water, providing $100 \% \mathrm{RH}$; saturated solution of potassium chloride, providing $87 \% \mathrm{RH}$; and saturated solution of sodium chloride attaining $76 \%$ RH, according to Jianhua and McDonald (1996). The seeds were distributed in a single layer on a screen tray connected to a plastic box containing $40 \mathrm{~mL}$ of distilled water or corresponding saturated solution at the bottom. The boxes were then closed and wrapped in plastic bags of $0.05 \mathrm{~mm}$ thickness and kept at $41^{\circ} \mathrm{C}$ 
in a B.O.D. chamber for 24,48 , and 72 hours. After the period of exposure, the moisture content of the seeds and their vigor was determined using the same procedure as the germination test, with counting performed on the fourth day.

The electrical conductivity test was conducted by the mass method. Four subsamples were used with approximately $0.45 \mathrm{~g}$ of seeds, weighed on a balance with a precision of $0.001 \mathrm{~g}$. The samples were placed in plastic cups for pre-soaking in $50 \mathrm{~mL}$ of distilled and deionized water at $25^{\circ} \mathrm{C}$ for 2,4 , and 8 hours and without soaking (before setting up the electrical conductivity test). After this period, the water was discarded and, once more, $50 \mathrm{~mL}$ of distilled and deionized water was added and exposed to $25^{\circ} \mathrm{C}$. After 4, 8, 16, and 24 hours of soaking, the electrical conductivity of the solution was determined with a bench-top conductivity meter. After the readings, the values of electrical conductivity were calculated per gram of seeds placed for soaking, and the results were expressed in $\mu \mathrm{S} . \mathrm{cm}^{-1} \cdot \mathrm{g}^{-1}$.

The experiment was conducted in a completely randomized design with four replications and analyzed by one-way analysis of variance for the moisture content, germination, first count, emergence, and ESI tests. The accelerated aging test was analyzed in a $6 \times 3 \times 3$ factorial arrangement, corresponding to 6 seed lots, 3 solutions, and 3 periods of exposure, respectively. The electrical conductivity test was composed of a $6 \times 4 \times$ 4 factorial arrangement, corresponding to 6 seed lots, 4 pre-soaking periods, and 4 soaking periods, respectively. The data obtained were subjected to the normality and homoscedasticity test. The Normal distribution of errors was evaluated by the Shapiro-Wilks test and theequality of variance, homoscedasticity, by Tukey test. . After that, analysis of variance was carried out by the $\mathrm{F}$ test and the mean values were compared by the Scott-Knott test at $5 \%$ significance.

\section{RESULTS AND DISCUSSION}

The moisture content of crambe seeds was around $8 \%$ (Table 1), a moisture level characteristic of oilseed species (Burrell et al., 1980) and adequate for initiating the assessments since there was no statistical difference among the lots.

By the germination test, it is possible to separate the lots into five levels in regard to physiological quality. Lot 6 was of highest quality, while lot 4 was of least quality and the only lot outside of commercial standards (Table 1) since it had a germination percentage of less than $75 \%$ (Brasil, 1968). The difference among the germination of the lots was not observed in seedling emergence. Only one lot was statistically lower. Therefore it is necessary to apply other vigor tests for evaluation of physiological quality of crambe seed.

The first count germination test is considered a parameter for assessment of seed vigor because, in the deterioration process, the speed of germination is affected (Nakagawa, 1994). Lot 6, in spite of having the best germination performance, did not have the greatest vigor by the assessment of the first count, but was considered as having intermediate vigor, while the lowest performance was once more attributed to Lot 4 .

For a lot to be considered as having greater vigor by the emergence test, it must exhibit a high percentage of emergence in relation to the other lots (Nakagawa, 1994).

Table 1 - Mean values of moisture content, germination, first count germination, seedling emergence, and Emergence Speed Index (ESI).

\begin{tabular}{|c|c|c|c|c|c|}
\hline \multirow{2}{*}{ Lot } & Moisture content & Germination & First count & Emergence & \multirow[t]{2}{*}{ ESI } \\
\hline & \multicolumn{4}{|c|}{------------------------------- \% --------------------------------- } & \\
\hline 1 & $8.4 \mathrm{a}$ & $81 \mathrm{c}$ & $33 \mathrm{~b}$ & $71 \mathrm{a}$ & $9.36 \mathrm{a}$ \\
\hline 2 & $8.5 \mathrm{a}$ & $84 \mathrm{c}$ & $57 \mathrm{a}$ & $67 \mathrm{a}$ & $9.12 \mathrm{a}$ \\
\hline 3 & $8.9 \mathrm{a}$ & $76 \mathrm{~d}$ & $36 \mathrm{~b}$ & $68 \mathrm{a}$ & $8.05 \mathrm{~b}$ \\
\hline 4 & $8.5 \mathrm{a}$ & $06 \mathrm{e}$ & $06 \mathrm{c}$ & $56 \mathrm{~b}$ & $7.38 \mathrm{~b}$ \\
\hline 5 & $8.5 \mathrm{a}$ & $88 \mathrm{~b}$ & $55 \mathrm{a}$ & $69 \mathrm{a}$ & $8.29 \mathrm{~b}$ \\
\hline 6 & $8.7 \mathrm{a}$ & $94 \mathrm{a}$ & $36 \mathrm{~b}$ & $73 \mathrm{a}$ & $9.78 \mathrm{a}$ \\
\hline CV (\%) & 8.52 & 4.51 & 13.27 & 4.25 & 7.34 \\
\hline
\end{tabular}

*Mean values followed by the same letter in the column do not differ statistically among themselves at the level of $5 \%$ significance by the Scott-Knott test. 
Based on this premise, it was possible to differentiate the lots studied into two levels of vigor and thus once more verify the inferior result of Lot 4 in relation to the others. The emergence test was not sensitive enough to distinguish the lots in more levels in regard to physiological quality. Similar behavior was observed for the emergence speed index, which also allowed classification of the lots into only two levels of vigor high and low vigor (Table 1).

The moisture contents of the six seed lots of crambe seeds after the accelerated aging tests showed statistical differences for all the treatments (Table 2).
Jianhua and McDonald (1996) affirmed that the use of saline solutions in the accelerated aging test leads to a reduction of relative humidity inside the plastic boxes. This behavior was observed when the potassium chloride and sodium chloride salts were used, in which the moisture up to the period of 72 hours did not statistically differ from the initial moisture of the seeds for the six lots under study (Table 2). Nevertheless, when the seeds were subjected to the methodology of the traditional aging test (with water), water gain increased in accordance with the period of exposure, and was specific for each lot in relation to initial moisture.

Table 2 - Moisture content (\%) in seed lots of crambe after accelerated aging in water, saturated solution of potassium chloride $(\mathrm{KCl})$, and saturated solution of sodium chloride $(\mathrm{NaCl})$ after three aging periods at the temperature of $41^{\circ} \mathrm{C}$.

\begin{tabular}{|c|c|c|c|c|}
\hline \multirow{3}{*}{$\begin{array}{l}\text { Solution } \\
\text { Seed lot }\end{array}$} & \multicolumn{4}{|c|}{ Moisture content $(\%)$} \\
\hline & \multicolumn{4}{|c|}{ Water } \\
\hline & 0 hours & 24 hours & 48 hours & 72 hours \\
\hline 1 & $8.4 \mathrm{aB}$ & $32.8 \mathrm{aA}$ & $32.3 \mathrm{cA}$ & $35.5 \mathrm{bA}$ \\
\hline 2 & $8.5 \mathrm{aB}$ & $33.3 \mathrm{aA}$ & $32.5 \mathrm{cA}$ & $35.5 \mathrm{bA}$ \\
\hline 3 & $8.9 \mathrm{aB}$ & $33.7 \mathrm{aA}$ & $32.5 \mathrm{cA}$ & $36.5 \mathrm{aA}$ \\
\hline 4 & $8.5 \mathrm{aB}$ & $28.8 \mathrm{bA}$ & $26.6 \mathrm{dA}$ & $33.2 \mathrm{dA}$ \\
\hline 5 & $8.5 \mathrm{aB}$ & $30.6 \mathrm{bA}$ & $33.4 \mathrm{bA}$ & $34.7 \mathrm{cA}$ \\
\hline 6 & $8.7 \mathrm{aC}$ & $29.4 \mathrm{bB}$ & $24.7 \mathrm{eB}$ & $38.2 \mathrm{bA}$ \\
\hline Solution & \multicolumn{4}{|c|}{$\mathrm{KCl}$} \\
\hline Seed lot & 0 hours & 24 hours & 48 hours & 72 hours \\
\hline 1 & $8.4 \mathrm{aA}$ & $10.3 \mathrm{dA}$ & $10.5 \mathrm{dA}$ & $13.4 \mathrm{aA}$ \\
\hline 2 & $8.5 \mathrm{aA}$ & $13.5 \mathrm{bA}$ & $13.7 \mathrm{bA}$ & $13.1 \mathrm{aA}$ \\
\hline 3 & $8.9 \mathrm{aA}$ & $14.8 \mathrm{aA}$ & $14.5 \mathrm{aA}$ & $13.7 \mathrm{aA}$ \\
\hline 4 & $8.5 \mathrm{aA}$ & $12.5 \mathrm{cA}$ & $12.3 \mathrm{cA}$ & $11.4 \mathrm{cA}$ \\
\hline 5 & $8.5 \mathrm{aA}$ & $13.4 \mathrm{bA}$ & $13.3 \mathrm{bA}$ & $13.4 \mathrm{aA}$ \\
\hline 6 & $8.7 \mathrm{aA}$ & $13.5 \mathrm{bA}$ & $13.7 \mathrm{bA}$ & $13.1 \mathrm{aA}$ \\
\hline Solution & \multicolumn{4}{|c|}{$\mathrm{NaCl}$} \\
\hline Seed lot & 0 hours & 24 hours & 48 hours & 72 hours \\
\hline 1 & $8.4 \mathrm{aA}$ & $11.5 \mathrm{aA}$ & $13.7 \mathrm{aA}$ & $9.7 \mathrm{bA}$ \\
\hline 2 & $8.5 \mathrm{aA}$ & $10.3 \mathrm{aA}$ & $10.1 \mathrm{bA}$ & $10.5 \mathrm{aA}$ \\
\hline 3 & $8.9 \mathrm{aA}$ & $10.2 \mathrm{aA}$ & $10.5 \mathrm{bA}$ & $9.5 \mathrm{bA}$ \\
\hline 4 & $8.5 \mathrm{aA}$ & $9.8 \mathrm{aA}$ & $10.3 \mathrm{bA}$ & $9.7 \mathrm{bA}$ \\
\hline 5 & $8.5 \mathrm{aA}$ & $10.3 \mathrm{aA}$ & $10.5 \mathrm{bA}$ & $9.9 \mathrm{bA}$ \\
\hline 6 & $8.7 \mathrm{aA}$ & $9.5 \mathrm{aA}$ & $9.4 \mathrm{cA}$ & $9.4 \mathrm{bA}$ \\
\hline
\end{tabular}

*Mean values followed by the same lowercase letter in the column and uppercase letter in the row are not statistically different among themselves at the level of $5 \%$ significance by the Scott-Knott test. 
The results of germination in the accelerated aging test with water and with potassium and sodium chloride saline solutions in the different periods of exposure to the temperature of $41^{\circ} \mathrm{C}$ are shown in table 3 . By the mean values obtained, it is possible to differentiate the lots into vigor levels for all the treatments in the accelerated aging test.

In the aging method with water and with the saline solutions in the periods studied, no lot stood out in the same manner; nevertheless, the treatment with water for
72 hours was that which provided better distinction in regard to physiological quality among the seed lots of crambe, allowing separation into five vigor levels, with Lot 6 standing out, similar to the germination test (Table 1). Werner et al. (2013) and Cruz et al. (2013) also mention the effectiveness of the use of accelerated aging with water as a test for determination of vigor, with exposure of the seeds for 72 hours in the same species. Cruz et al. (2013), moreover, recommend the time of 96 hours for the seeds to remain in the aging chamber with water.

Table 3 - Accelerated aging test in seed lots of crambe, using water or potassium chloride $(\mathrm{KCl})$ and sodium chloride $(\mathrm{NaCl})$ saturated saline solution in different periods of exposure to the temperature of $41^{\circ} \mathrm{C}$.

\begin{tabular}{|c|c|c|c|}
\hline & \multicolumn{3}{|c|}{$\mathrm{AA}(\%)$} \\
\hline Solution & \multicolumn{3}{|c|}{ Water } \\
\hline Seed lot & 24 hours & 48 hours & 72 hours \\
\hline 1 & $51 \mathrm{dA}$ & $55 \mathrm{bA}$ & $52 \mathrm{bA}$ \\
\hline 2 & $55 \mathrm{cA}$ & $56 \mathrm{bA}$ & $10 \mathrm{eB}$ \\
\hline 3 & $46 \mathrm{dA}$ & $50 \mathrm{bA}$ & $44 \mathrm{cA}$ \\
\hline 4 & $75 \mathrm{aA}$ & $53 \mathrm{bB}$ & $17 \mathrm{dC}$ \\
\hline 5 & $61 \mathrm{bA}$ & $37 \mathrm{cB}$ & $57 \mathrm{bA}$ \\
\hline \multirow[t]{2}{*}{6} & $76 \mathrm{aA}$ & $63 \mathrm{aB}$ & $67 \mathrm{aB}$ \\
\hline & \multicolumn{3}{|c|}{$\mathrm{KCl}$} \\
\hline Seed lot & 24 hours & 48 hours & 72 hours \\
\hline 1 & $61 \mathrm{bA}$ & $56 \mathrm{bA}$ & $57 \mathrm{bA}$ \\
\hline 2 & $53 \mathrm{cA}$ & $53 \mathrm{bA}$ & $20 \mathrm{db}$ \\
\hline 3 & $45 \mathrm{dA}$ & $32 \mathrm{~dB}$ & $41 \mathrm{cA}$ \\
\hline 4 & $75 \mathrm{aA}$ & $65 \mathrm{aB}$ & $56 \mathrm{bC}$ \\
\hline 5 & $59 \mathrm{bA}$ & $30 \mathrm{dC}$ & $43 \mathrm{cB}$ \\
\hline \multirow[t]{2}{*}{6} & $59 \mathrm{bB}$ & $50 \mathrm{cC}$ & $67 \mathrm{aA}$ \\
\hline & \multicolumn{3}{|c|}{$\mathrm{NaCl}$} \\
\hline Seed lot & 24 hours & 48 hours & 72 hours \\
\hline 1 & $76 \mathrm{aA}$ & $57 \mathrm{aB}$ & $51 \mathrm{aC}$ \\
\hline 2 & $65 \mathrm{cA}$ & $59 \mathrm{aB}$ & $46 \mathrm{bC}$ \\
\hline 3 & $47 \mathrm{dA}$ & $43 \mathrm{cA}$ & $33 \mathrm{~dB}$ \\
\hline 4 & $72 \mathrm{bA}$ & $64 \mathrm{aB}$ & $49 \mathrm{cC}$ \\
\hline 5 & $67 \mathrm{cA}$ & $61 \mathrm{aB}$ & $46 \mathrm{bC}$ \\
\hline 6 & $79 \mathrm{aA}$ & $48 \mathrm{bB}$ & $52 \mathrm{aB}$ \\
\hline CV (\%) & $7.00 \%$ & & \\
\hline
\end{tabular}

* Mean values followed by the same lowercase letter in the column and uppercase letter in the row are not statistically different among themselves at the level of $5 \%$ significance by the Scott-Knott test. 
Nery et al. (2009) mention that it is possible to distinguish seed lots of oilseed radish after 72 hours when the $\mathrm{NaCl}$ saturated solution was used. In that study, the use of $\mathrm{NaCl}$ allowed differentiation of the seed lots of crambe after 72 hours; nevertheless, aging with water was more rigorous, leading to greater differentiation of the lots. Toledo et al. (2011) did not detect a temperature and period of exposure adequate for the crambe seeds in the accelerated aging test with water which would provide for better distinction of the lots assessed in relation to physiological quality. Santos and Rosseto (2013) report that the use of sodium chloride saturated solution for 48 hours is capable of distinguishing seed lots of crambe in different vigor levels, diverging from what was observed in this study.
The water content of the seeds in the realization of electrical conductivity test is of utmost importance in the standardization of the test method, as well as in obtaining consistent results between laboratories and within the same laboratory. Lots with differents water contet have differents responses to the electrical conductivity test. Seeds with lower water content tend to significant increases in conductivity values. The water content of crambe seed lots (Table 1) was uniform (in the range of $8.7 \%$ ) and did not differ statistically. The maximum variation between lots was $0.5 \%$, being suitable for conduction of the electrical conductivity test.

In relation to adaptation of the method of the electrical conductivity test (Table 4), it is observed that the quantity of levels in which the lots were classified was

Table 4 - Electrical conductivity in six seed lots of crambe as a function of periods of pre-soaking and soaking times at $25^{\circ} \mathrm{C}$.

\begin{tabular}{|c|c|c|c|c|c|}
\hline \multirow[b]{2}{*}{ Soaking time } & \multirow[b]{2}{*}{ Lots } & \multicolumn{4}{|c|}{ Pre-soaking (hours) } \\
\hline & & 0 & 2 & 4 & 8 \\
\hline \multirow{6}{*}{4 hours } & 1 & $509.14 \mathrm{~b}$ & $92.74 \mathrm{~b}$ & $54.69 \mathrm{~b}$ & $35.69 \mathrm{~b}$ \\
\hline & 2 & $556.18 \mathrm{a}$ & $133.04 \mathrm{a}$ & $77.76 \mathrm{a}$ & $53.03 \mathrm{a}$ \\
\hline & 3 & $566.80 \mathrm{a}$ & $106.54 \mathrm{~b}$ & $69.74 \mathrm{a}$ & $38.35 \mathrm{~b}$ \\
\hline & 4 & $553.08 \mathrm{a}$ & $93.33 \mathrm{~b}$ & $50.14 \mathrm{~b}$ & $34.13 b$ \\
\hline & 5 & $438.40 \mathrm{~d}$ & $80.57 \mathrm{c}$ & $54.57 \mathrm{~b}$ & $33.92 \mathrm{~b}$ \\
\hline & 6 & $485.48 \mathrm{c}$ & $86.84 \mathrm{c}$ & $69.16 \mathrm{a}$ & $38.44 \mathrm{~b}$ \\
\hline Soaking time & Lots & 0 & 2 & 4 & 8 \\
\hline \multirow{6}{*}{8 hours } & 1 & $523.03 \mathrm{~d}$ & $103.35 \mathrm{c}$ & $60.12 \mathrm{~b}$ & $43.44 \mathrm{~b}$ \\
\hline & 2 & $553.14 \mathrm{~b}$ & $146.29 \mathrm{a}$ & $87.55 \mathrm{a}$ & $60.00 \mathrm{a}$ \\
\hline & 3 & $594.68 \mathrm{a}$ & $120.24 \mathrm{~b}$ & $78.60 \mathrm{a}$ & $46.95 \mathrm{~b}$ \\
\hline & 4 & $543.45 \mathrm{c}$ & $103.07 \mathrm{c}$ & $65.13 \mathrm{~b}$ & $43.54 \mathrm{~b}$ \\
\hline & 5 & $443.22 \mathrm{e}$ & $85.02 \mathrm{~d}$ & $62.18 \mathrm{~b}$ & $41.06 \mathrm{~b}$ \\
\hline & 6 & $513.96 \mathrm{~d}$ & $95.61 \mathrm{~d}$ & $80.56 \mathrm{a}$ & $46.52 \mathrm{~b}$ \\
\hline Soaking time & Lots & 0 & 2 & 4 & 8 \\
\hline \multirow{6}{*}{16 hours } & 1 & $630.28 \mathrm{c}$ & $140.45 \mathrm{c}$ & $88.66 \mathrm{~b}$ & $61.28 \mathrm{~b}$ \\
\hline & 2 & $669.85 \mathrm{a}$ & $187.72 \mathrm{a}$ & $119.73 \mathrm{a}$ & $88.72 \mathrm{a}$ \\
\hline & 3 & $669.41 \mathrm{a}$ & $163.53 \mathrm{~b}$ & $108.42 \mathrm{a}$ & $71.03 \mathrm{~b}$ \\
\hline & 4 & $650.45 \mathrm{~b}$ & $140.63 \mathrm{c}$ & $88.13 \mathrm{~b}$ & $64.90 \mathrm{~b}$ \\
\hline & 5 & $552.02 \mathrm{e}$ & $111.94 \mathrm{e}$ & $87.32 \mathrm{~b}$ & $58.79 \mathrm{~b}$ \\
\hline & 6 & $609.96 \mathrm{~d}$ & $127.02 \mathrm{~d}$ & $112.91 \mathrm{a}$ & $66.91 \mathrm{~b}$ \\
\hline
\end{tabular}

Continue... 
Table 4 - Continued...

\begin{tabular}{cccccc}
\hline Soaking time & Lots & 0 & 2 & 4 & 8 \\
\hline \multirow{6}{*}{24 hours } & 1 & $636.41 \mathrm{~d}$ & $149.72 \mathrm{c}$ & $91.21 \mathrm{c}$ & $68.81 \mathrm{c}$ \\
& 2 & $699.02 \mathrm{~b}$ & $196.71 \mathrm{a}$ & $131.01 \mathrm{a}$ & $103.51 \mathrm{a}$ \\
& 3 & $727.35 \mathrm{a}$ & $174.67 \mathrm{~b}$ & $116.80 \mathrm{a}$ & $87.04 \mathrm{~b}$ \\
& 4 & $674.25 \mathrm{c}$ & $154.57 \mathrm{c}$ & $102.57 \mathrm{~b}$ & $76.52 \mathrm{c}$ \\
& 5 & $590.48 \mathrm{e}$ & $119.48 \mathrm{e}$ & $88.94 \mathrm{c}$ & $61.09 \mathrm{c}$ \\
& 6 & $660.00 \mathrm{c}$ & $136.11 \mathrm{~d}$ & $126.48 \mathrm{a}$ & $78.01 \mathrm{c}$ \\
\hline
\end{tabular}

* Mean values followed by the same letter in the column do not differ statistically among themselves at the level of 5\% significance by the Scott-Knott test.

always greater when there was no pre-soaking treatment of the seeds for carrying out the test. It is also observed that in the time of soaking of 16 and 24 hours and of presoaking of 2 hours, the number of levels in which the lots were differentiated is equated with that observed in the treatment without pre-soaking for the same periods of soaking. It is noteworthy that the better result obtained by Lot 5 was similar to that obtained for the first count germination (Table 1).

The results obtained in the electrical conductivity test were consistent with the principles of the test, given that as the time of pre-soaking of the seeds increases, the membrane system is reconstituted and leaching decreases (Table 4).

This behavior was observed by Barbosa et al. (2012) in peanut seeds. Thus, the more disorganized the membrane system is, the greater the quantity of leachates lost at the beginning of pre-soaking will be, and, therefore, the discrimination of lots in different qualities will be greater (Kryzanowsky; Vieira; Franca-Neto, 1999).

Nevertheless, it is important to consider that the introduction of pre-soaking in the electrical conductivity test may improve the precision of the results to the extent that measurements of electrolytes aggregated on the outside of the seeds are excluded. In this study, it was possible to carry out pre-soaking for 2 hours without detriment to the number of classes in which the lots were divided up, as long as the reading of conductivity is made for a time greater than 16 hours of soaking.

In the face of the results obtained from electrical conductivity, it may be observed that it is possible to differentiate seed lots of crambe after 16 hours of soaking with a pre-soaking of 2 hours. The viability of reduction in testing time for electrical conductivity was a point of divergence in the recommendation of Santos and Rosseto (2013), who suggest the time of 24 hours of soaking for execution of the test on crambe seeds. However, Cruz et al. (2013) did not obtain satisfactory results for recommendation of a methodology for the electrical conductivity test in this same species. In other oilseed species, such as canola (Milani, Menezes; Lopes, 2012) and sesame seed (Torres et al., 2009), a reduction in time for assessment of the electrical conductivity test was also recommended.

\section{CONCLUSION}

The accelerated aging test with water for the period of 72 hours and the electrical conductivity test, with pre-soaking for 2 hours and assessment after 16 hours of soaking distinguish lots of crambe seeds with respect to the vigor.

\section{REFERENCES}

ASSOCIATION OF OFFICIAL SEED ANALYSTS AOSA. Seed vigor testing handbook. East Lansing: AOSA, 1983. 93p. (Contribution, 32).

BARBOSA, R.M. et al. Condutividade elétrica em função do teor de água inicial de sementes de amendoim. Ciência Rural. 42(1):45-51, 2012.

BRASIL. Ministério da Agricultura, Pecuária e Abastecimento/Secretaria de Defesa Agropecuária.

Portaria 457. Diário Oficial da República Federativa do Brasil, Brasília, Seção 1, p.19653, 1986.

BRASIL. Ministério da Agricultura, Pecuária e Abastecimento. Regras para Análises de Sementes. Ministério da Agricultura, Pecuária e Abastecimento. Secretaria de Defesa Agropecuária. Brasília, DF: Mapa/ ACS, 2009. 395p. 
BURRELL, N.J. et al. Determination of the time available for drying rapeseed before the appearance of surface moulds. Journal of Stored Products Research. 16(3/4):115-118. 1980.

CARDOSO, R.B.; BINOTTI, F.F. S. da; CARDOSO, E.D. Potencial fisiológico de sementes de crambe em função de embalagens e armazenamento. Pesquisa Agropecuária Tropical. 42(3):272-278, 2012.

CRUZ, S.M. et al. Vigor tests for evaluation of crambe (Crambe abyssinica Hochst) seed quality. Journal of Seed Science. 35(4):485-494, 2013.

HAMPTON, J.G.; TEKONY, D.M. Handbook of vigour test methods. 3. ed. Zürich, 1995. ISTA, 117p.

JASPER, S.P.; BIAGGIONI, M.A.M.; SILVA, P.R.A. Comparação do custo de produção do crambe (Crambe abyssinica Hochst) com outras culturas oleaginosas em sistema de plantio direto. Revista Energia na Agricultura. 25(4):141-153, 2010.

JIANHUA, Z.; MC DONALD, M. B. The saturated salt accelerated aging test for small seeds crops. Seed Science and Techology. 25(1):123-131, 1996.

KRZYZANOWSKI, F.; VIEIRA, R.D.; FRANCANETO, J. B. Vigor de sementes: conceitos e testes. Londrina: ABRATES, 1999. 218p.

MAGUIRE, J. D. Speed of germination-aid in selection and evaluation for seedling emergence and vigor. Crop Science. 2(1):176-177, 1962.

MILANI, M.; MENEZES, N.L.; LOPES, S.J. Teste de condutividade elétrica para avaliação do potencial fisiológico de sementes de canola. Revista Ceres. 59(3):374-379, 2012.

NAKAGAWA, J. Testes de vigor baseados na avaliação das plântulas. In: VIEIRA, R.D.; CARVALHO, N.M.
Testes de vigor em sementes. Jaboticabal: FUNEP, p.49-85, 1994.

NERY, M.C. et al. Testes de vigor para avaliação da qualidade de sementes de nabo forrageiro. Informativo Abrates. 19(1):2009.

PAULOSE, B.; KANDASAMY, S.; DHANKHER, O.P. Expression profiling of Crambe abyssinica under arsenate stress identifies genes and gene networks involved in arsenic metabolism and detoxification. BMC Plant Biology. 10(108):1-12, 2010.

SANTOS, L.A.S.; ROSSETO, C.A.V. Testes de vigor em sementes de Crambe abyssinica. Ciência Rural. 43(2):233-238, 2013.

SOARES, M.M. et al. Testes para avaliação do vigor de sementes de sorgo em ênfase a condutividade elétrica.

Ciência e Agrotecnologia. 34(2):391-397, 2010.

SOUZA, A. D. V. et al. Caracterização química de sementes e tortas de pinhão-manso, nabo-forrageiro e crambe. Pesquisa Agropecuária Brasileira. 44(10):1328-1335, 2009.

TOLEDO, M.Z. et al. Physiological quality and enzymatic activity of crambe seeds after the accelerated aging test. Acta Scientiarum Agronomy. 33(4):687694, 2011.

TORRES, S.B. et al. Teste de condutividade elétrica em sementes de gergelim. Revista Brasileira de Sementes. 31(3):070-077, 2009.

WERNER, E.T. et al. Accelerated aging test to evaluate the quality of crambe (Crambe abyssinica Hochst Brassicaceae) seed physiology. IDESIA. 31(1), 2013.

VIEIRA, R.D. et al. Condutividade elétrica e teor de água inicial das sementes de soja. Pesquisa Agropecuária Brasileira. 37(9):1333-1338, 2002. 